\title{
ANALISIS KEMAMPUAN PENALARAN MATEMATIS BERDASARKAN GAYA BELAJAR SISWA
}

\author{
Novia Fauziah1, Yoni Sunaryo², Angra Meta Ruswana ${ }^{3}$ \\ 1,2,3 Program Studi Pendidikan Matematika, Universitas Galuh, JI. R.E. Martadinata No. 150, Ciamis, Indonesia \\ Email : novia.fauziah04@gmail.com
}

\begin{abstract}
This study aims to obtain an overview of mathematical reasoning abilities based on students' learning styles. This research is a qualitative descriptive study with a case study method. The objects in this study were eighth grade students in one of the Madrasah Tsanawiyah, Ciamis District, Baregbeg District as many as nine people. The data were collected using questionnaires, written tests and interviews. The results showed that students with visual type learning styles who had high, medium and low reasoning abilities were able to solve the given mathematical reasoning problems, with the obstacle of lack of accuracy, influenced by peers. Students with auditory learning styles and have high, medium and low reasoning abilities can solve the given mathematical reasoning problems, with obstacles students are more interested in solving problems by discussing. Students with kinesthetic learning styles and having high, medium and low reasoning abilities can solve the given mathematical reasoning problems, with obstacles students feel bored if they continue to study in class, lack interest in math subjects and cannot be silent so that the time given to do a lot of wasted problems.
\end{abstract}

Keywords: Reasoning Ability, Learning Style

\begin{abstract}
ABSTRAK
Penelitian ini bertujuan untuk memperoleh gambaran mengenai kemampuan penalaran matematis berdasarkan gaya belajar siswa. Penelitian ini merupakan penelitian deskriptif kualitatif dengan metode studi kasus.Objek pada penelitian ini adalah siswa kelas VIII di salah satu Madrasah Tsanawiyah daerah Ciamis Kecamatan Baregbeg sebanyak sembilan orang.Pengumpulan data menggunakan angket, tes tertulis dan wawancara. Hasil penelitian menunjukkan bahwa siswa dengan gaya belajar tipe visual yang memiliki kemampuan penalaran tinggi, sedang dan rendah dapat menyelesaikan soal penalaran matematis yang diberikan, dengan hambatan kurangnya ketelitian, terpengaruh oleh rekan. Siswa dengan gaya belajar auditori dan memiliki kemampuan penalaran tinggi, sedang dan rendah dapat menyelesaikan soal penalaran matematis yang diberikan, dengan hambatan siswa lebih tertarik jika menyelesaikan soal dengan cara berdiskusi. Siswa dengan gaya belajar kinestik dan memiliki kemampuan penalaran tinggi, sedang dan rendah dapat menyelesaikan soal penalaran matematis yang diberikan, dengan hambatan siswa merasa bosan jika terus-menerus belajar di kelas, kurang minat terhadap mata pelajaran matematika dan tidak bisa diam sehingga waktu yang diberikan untuk mengerjakan soal banyak terbuang.
\end{abstract}

Kata Kunci: Kemampuan Penalaran, Gaya Belajar

Cara sitasi: Fauziah, N., Sunaryo, Y., \& Ruswana, A, M. (2021). Analisis Kemampuan Penalaran Matematis Berdasarkan Gaya Belajar Siswa. J-KIP (Jurnal Keguruan dan IImu Pendidikan), 2 (3), 119-124. 


\section{PENDAHULUAN}

Pendidikan adalah hal yang terpenting dalam kehidupan kita. Pendidikan merupakan hal penting dalam rangka meningkatkan kualitas Sumber Daya Manusia baik dari segi spiritual, intelegensi, maupun skill untuk menunjang kehidupannya (Sopiah et al., 2020). Pendidikan tidak lepas dari kedisiplinan ilmu yang sangat erat hubungannya dengan kehidupan sehari-hari. Salah satu tujuan pengelolaan dan penyelenggaraan pendidikan di Indonesia yaitu membangun landasan bagi berkembangnya potensi siswa agar menjadi manusia yang berilmu, cakap, kritis, kreatif, dan inovatif. Hal ini sejalan dengan proses pembelajaran kurikulum 2013 yang diselenggarakan secara interaktif, inspiratif, menyenangkan, menantang, memotivasi siswa untuk berpartisipasi aktif, serta memberikan ruang yang cukup bagi prakarsa, kreativitas, dan kemandirian sesuai dengan bakat, minat, dan perkembangan fisik serta psikologis siswa.

National Council of Teacher of Mathematics (NCTM, 2000) mengatakan bahwa dalam pelaksanaan pembelajaran matematika, guru harus memperhatikan lima kemampuan matematis yaitu: koneksi (connections), penalaran (reasoning), komunikasi (communications), pemecahan masalah (problem solving), dan representasi (representations). Oleh karena itu, guru memiliki peranan untuk menumbuhkan kemampuan penalaran matematis dalam diri siswa baik dalam metode pembelajaran yang dipakai, ataupun dalam evaluasi berupa pembuatan soal yang mendukung.

"Penalaran merupakan alat yang sangat penting untuk matematika dan juga kehidupan sehari-hari. Sehingga dapat diartikan bahwa siswa akan dapat memahami konsep yang benar dalam mempelajari matematika dan untuk mencetuskan ide, siswa memerlukan kemampuan penalaran" (Baroody \& Niskayuna, 1993). Penetapan kemampuan penalaran sebagai tujuan dan visi pembelajaran matematika merupakan sebuah bukti bahwa kemampuan penalaran sangat penting untuk dimiliki siswa kemampuan penalaran matematis yaitu kemampuan menghubungkan permasalahan-permasalahan ke dalam suatu ide atau gagasan sehingga dapat menyelesaikan permasalahan matematis.

Kemampuan penalaran matematis siswa dipengaruhi oleh beberapa faktor seperti karakteristik belajar, kurangnya rasa percaya diri, lingkungan, serta kurangnya kepercayaan dari orang tua. Salah satu karakteristik siswa yang berpengaruh terhadap hasil belajar adalah gaya belajar. Gaya belajar merupakan suatu tindakan yang dirasakan menarik oleh siswa dalam melakukan aktivitas belajar, baik ketika sedang sendiri atau dalam kelompok belajar bersamasama teman sekolah (Sopiatin \& Sahrani, 2011). Gaya belajar merupakan modalitas belajar yang sangat penting. Menurut Hasrul (2010) "Gaya belajar merupakan suatu kombinasi dari bagaimana seseorang menyerap dan kemudian mengatur serta mengolah informasi. Berdasarkan dari faktor tersebut bahwa setiap siswa pasti memiliki gaya belajar yang berbeda, Sidjabat (Ghufron \& Risnawita, 2014) "Dua anak yang tumbuh dalam kondisi dan lingkungan yang sama dan meskipun mendapatkan perlakuan yang sama belum tentu akan memiliki pemahaman, pemikiran dan pandangan yang sama terhadap dunia.

Tiga jenis gaya belajar berdasarkan modalitas sensori yaitu gaya belajar visual (cara melihat), gaya belajar auditori (cara mendengar), dan gaya belajar kinestetik (belajar melalui gerak dan sentuhan). Setiap siswa pasti memiliki ketiga modalitas ini, namun seseorang biasanya memiliki hanya satu jenis modalitas yang lebih menonjol.

Peneliti melakukan wawancara dengan guru mata pelajaran matematika di MTs Darul Ulum tentang permasalahan matematika di sekolah tersebut. Menurutnya tingkatan kemampuan penalaran matematis siswa masih rendah, sehingga siswa kesulitan dalam menyelasaikan masalah yang disajikan oleh guru. Berdasarkan uraian tersebut sehingga membuat penulis untuk melakukan suatu penelitian yang berjudul "Analisis Kemampuan Penalaran Matematis Berdasarkan Gaya Belajar Siswa". 
Tujuan dilakukannya penelitian untuk mengetahui kemampuan penalaran matematis siswa berdasarkan gaya belajar. Penelitian ini terdapat batasan masalah untuk membatasi pembahasan pada pokok permasalahan saja sehingga masalah-masalah dalam penelitian dapat dimengerti dengan mudah dan baik. Ruang lingkup penelitian ini yaitu mengetahui kemampuan penalaran matematis berdasarkan gaya belajar siswa pada gaya belajar tipe visual, tipe auditori dantipe kinestik, sampel dari penelitian ini adalah siswa kelas VIII yang memiliki hasil belajar tinggi, sedang dan rendah pada materi Teorema Pythagoras.

\section{METODE PENELITIAN}

Jenis penelitian ini adalah penelitian kualitatif, metode penelitian yang digunakan studi kasus. Objek penelitian ini mengenai kemampuan penalaran matematis yang dilihat dari gaya belajar siswa. Penelitian ini dilakukan pada siswa kelas VIII MTS DARUL ULUM Baregbeg dengan memberikan angket gaya belajar, memberikan soal tes kemampuan penalaran matematis, melakukan wawancara dan dokumentasi guna mendapatkan data yang akurat ketika di lapangan untuk mengetahui gaya belajar yang dimiliki siswa dengan mengklasifikasikan kemampuan matematika siswa berdasarkan klasifikasi nilai matematika siswa dengan nilai tinggi, nilai sedang dan nilai rendah. Objek penelitian berjumlah 20 orang dan dipilih 9 orang yang dikategorikan menurut kemampuan matematis siswa dan dipilih berdasarkan pertimbangan guru dengan mengacu pada nilai hasil belajar siswa. Subjek dipilih 3 orang dari tiap kelompok dengan alasan hasil tes dari 3 subjek tersebut dapat dijadikan bahan perbandingan pada analisis data tiap kelompok yang akan diteliti.

\section{HASIL DAN PEMBAHASAN}

Tes kemampuan penalaran matematis berdasarkan gaya belajar siswa dilaksanakan terhadap 9 orang siswa yang memiliki kemampuan penalaran matematis tinggi, sedang dan rendah. Berikut penulis sajikan data mengenai objek penelitian pada Tabel 1.

Tabel 1. Daftar Subjek Penelitian

\begin{tabular}{cccc}
\hline No. & Kode & Tipe Gaya Belajar & Kategori Kemampuan Siswa \\
\hline 1 & AF & V1 & Tinggi \\
2 & YN & A1 & Tinggi \\
3 & HN & K1 & Tinggi \\
4 & Ml & V2 & Sedang \\
5 & ML & K2 & Sedang \\
6 & UT & A2 & Sedang \\
7 & NK & K3 & Rendah \\
8 & AFW & A3 & Rendah \\
9 & Al & V3 & Rendah \\
\hline
\end{tabular}

Data tes diperoleh dari hasil tes kemampuan penalaran matematis kepada siswa yang telah mendapatkan pembelajaran materi teorema Pythagoras dan disajikan dalam bentuk soal uraian (essay) sebanyak 6 butir soal. Soal tersebut memuat indikator-indikator kemampuan penalaran matematis dan telah teruji coba. Alokasi waktu pada tes tersebut selama 60 menit. Data selanjutnya diperoleh dari hasil wawancara kepada siswa setelah selesai mengerjakan soal tes kemampuan penalaran matematis. Wawancara tersebut bertujuan untuk mengetahui kemampuan penalaran matematis siswa secara lebih mendalam, mengetahui kemampuan siswa dalam menyelesaikan soal tes dan pemahaman siswa pada materi Teorema Pythagoras. 
Berdasarkan hasil analisis soal nomor 1 dengan kategori sedang terhadap siswa yang memiliki kemampuan matematis tinggi yaitu subjek $\mathrm{AF}(\mathrm{V} .1)$ dan $\mathrm{HN}(\mathrm{K} .1)$ mampu memahami soal dengan baik sehingga mampu menjawab soal dengan tepat. Subjek YN(A.1) juga mampu memahami soal dengan baik dan menjawab soal dengan tepat dalam menjawab soal pada nomor 1 yaitu menghubungkan jalan yang diketahui. Sedangkan siswa dengan matematis sedang, subjek UT,MI dan ML mampu memahami soal, mampu menjelaskan cara apa yang tepat digunakan untuk menentukan jarak terpendek, ketiganya mampu menjelaskan apa yang diketahui dari soal, dan memiliki anggapan bahwa jarak terpendek yaitu menghubungkan jalan juanda dengan jalan merdeka. Hal serupa juga terjadi pada siswa dengan kemampuan matematis rendah, subjek AFW(A.3), NK(K.3) dan Al(V.3) mampu memahami soal namun tidak mampu menjelaskan cara apa yang tepat digunakan untuk menentukan jalan terpendek.

Analisis selanjutnya adalah soal nomor 2 dengan kategori mudah terhadap siswa yang memiliki kemampuan matematis tinggi yaitu subjek $\mathrm{AF}(\mathrm{V} .1)$ dan $\mathrm{HN}(\mathrm{K} .1)$ cenderung mampu memahami soal dengan baik sehingga mampu menggambarkan jawaban secara matematis dan tepat. Namun subjek YN(A.1) hanya mampu memahami soal namun tidak mampu menggambarkan jawaban dengan tepat, karena masih terdapat kekeliruan pada saat memilih gambar phytagoras. Hal serupa juga terjadi pada siswa dengan matematis sedang, subjek UT(A.2), MI(V.2) hanya mampu memahami soal namun tidak mampu menggambarkan jawaban dengan tepat, kekeliruan subjek UT(A.2) sama seperti yang dilakukan oleh subjek YN(A.1) yaitu saat memilih gambar phytagoras. Sedangkan subjek ML(K.2) yang juga memiliki kemampuan matematis sedang cenderung tidak mampu memahami soal dengan baik sehingga terjadi beberapa kesalahan ketika menggambarkan jawaban secara matematis. Siswa dengan kemampuan matematis rendah, subjek AFW(A.3), NK(A.1) dan Al(V.3) cenderung tidak mampu memahami soal sehingga tidak mampu menggambarkan jawaban secara matematis dan tepat.

Berdasarkan hasil analisis pada soal nomor 3 dengan kategori sulit terhadap siswa yang memiliki kemampuan matematis tinggi yaitu subjek $A F(V .1)$ dan $\mathrm{YN}(\mathrm{A} .1)$ mampu memberikan jawaban secara matematis dengan tepat. . Namun subjek HN(K.1) tidak mampu memahami soal namun keduanya masih mengalami kekeliruan dalam penulisan rumus teorema Pythagoras yang seharusnya. Subjek AF(V.1) dan YN(A.1) memenuhi indikator menarik kesimpulan,menyusun bukti, memberikan alasan atau bukti terhadap kebenaran solusi.Hal tersebut berbanding terbalik dengan subjek $\mathrm{HN}(\mathrm{K} .1)$ yang hanya memenuhi indikator menyusun bukti dan belum memenuhi indikator menarik kesimpulan dan memberikan alasan atau bukti terhadap kebenaran solusi. Sedangkan siswa dengan kemampuan matematis sedang dan rendah, subjek UT(A.2), MI(V.2), ML(K.2), UT(A.2), MI(V.2) dan ML(K.2) belum memahami soal dengan baik sehingga belum mampu memberikan jawaban secara matematis dan tepat. Subjek keenamnya mengalami kekeliruan dalam pengoperasian rumus, sehingga belum memenuhi indikator menyusun bukti, tidak memenuhui indikator menarik kesimpulan dan memberikan alasan atau bukti terhadap kebenaran solusi. Berbeda halnya dengan siswa yang memiliki kemampuan matematis rendah, subjek AFW(A.3), $\mathrm{NK}(\mathrm{K} .3)$ dan $\mathrm{Al}(\mathrm{V} .3)$ belum memahami soal dengan baik dan belum mampu menuliskan rumus serta jawaban dengan tepat. Ketiganya cenderung belum memenuhi indikator menyusun bukti, tidak memenuhui indikator menarik kesimpulan dan memberikan alasan atau bukti terhadap kebenaran solusi.

Berdasarkan hasil analisis pada soal nomor 4 dengan kategori mudah terhadap siswa yang memiliki kemampuan matematis tinggi yaitu subjek $A F(V .1)$, $H N(K .1)$ dan $Y N(A .1)$ mampu memberikan jawaban secara matematis dan tepatyaitu "termasuk tripel Pythagoras", dan menjelaskan jawaban dengan baik mengapa disimpulkan "termasuk tripel Pythagoras", namun hanya subjek $A F(V .1)$ dan $Y N(A .1)$ yang mampu memenuhi indikator menarik kesimpulan dari pernyataan. Sedangkan subjek $\mathrm{HN}(\mathrm{K} .1)$ hanya mampu memberikan jawaban secara sistematis 
tanpa menarik kesimpulan dari pernyataan. Pada siswa dengan kemampuan matematis sedang dan rendah. Enam subjek siswa yaitu UT(A.2), MI(V.2), ML(K.2),AFW(A.3), NK(K.3) dan AI(V.3) memenuhi indikator menarik kesimpulan dari pernyataan.

Berdasarkan hasil analisis pada soal nomor 5 dengan kategori sedang terhadap siswa yang memiliki kemampuan matematis tinggi yaitu subjek $\mathrm{AF}(\mathrm{V} .1)$, $\mathrm{HN}(\mathrm{K} .1)$ dan $\mathrm{YN}(\mathrm{A} .1)$ mampu menggambarkan jawaban secara matematis, memberikan jawaban dengan tepat. Ketiganya cenderung memenuhi indikator memeriksa kesahihan dari suatu argumen. Berbeda dengan siswa dengan kemampuan matematis sedang, subjek UT(A.2) dan ML(K.2) memenuhi indikator memeriksa kesahihan dari suatu argumen. Namun subjek MI(V.2) memberikan jawaban hasil penentuan garis beratnya tidak tepat. Begitupula siswa dengan kemampuan matematis rendah, yaitu subjek AFW(A.3), NK(K.3) dan Al(V.3) meskipun menjawab dengan tepat namun penentuan garis beratnya tidak tepat.

Berdasarkan hasil analisis pada soal nomor 6 dengan kategori sulit terhadap siswa yang memiliki kemampuan matematis tinggi yaitu subjek $\mathrm{AF}(\mathrm{V} .1)$ dan $\mathrm{HN}(\mathrm{K} .1)$ memenuhi indikator menemukan nilai dan sifat dari gejala matematis untuk membuat generalisasi. Keduanya menjawab secara matematis dan mampu menjelaskan jawabannya dengan baik, namun masih terdapat kekeliruan pada jawaban tersebut. Subjek YN(A.1) dapat menjawab secara matematis dan mampu menjelaskan jawabannya dengan baik, namun masih terdapat kekeliruan pada jawaban selanjutnya. Subjek YN(A.1) menjawab $1 / 2 \mathrm{~cm}$ pada penentuan nilai BC, sedangkan jawaban yang benar adalah $18 \mathrm{~cm}$. Hal serupa juga terjadi pada siswa dengan matematis sedang yaitu subjek UT(A.2), MI(V.2) dan $\mathrm{ML}(\mathrm{K} .2)$ cenderung belum memenuhi indikator menemukan nilai dan sifat dari gejala matematis untuk membuat generalisasi. Subjek UT(A.2) dan ML(K.2) menjawab $36 \mathrm{~cm}$ dan $1 / 2 \mathrm{~cm}$ pada panjang langkah kedua dan kedua, sedangkan jawaban yang tepat adalah $18 \mathrm{~cm}$. Subjek MI(V.2) tidak dapat menjawab secara matematis dan belum mampu menjelaskan jawabannya dengan baik. Begitupula siswa dengan kemampuan matematis rendah, yaitu subjek AFW(A.3), NK(K.3) dan Al(V.3) siswa dengan kemampuan matematis rendah, subjek UT(A.2) dan MI(V.2) memiliki kekeliruan yang sama dengan siswa yang kemampuan matematisnya sedang.

\section{KESIMPULAN}

Berdasarkan hasil penelitian dan pembahasan, dapat diambil simpulan bahwa siswa dengan gaya belajar tipe visual yang memiliki kemampuan penalaran tinggi, sedang dan rendah dapat menyelesaikan soal penalaran matematis yang diberikan, berdasarkan hal tersebut siswa dengan gaya belajar tipe visual yang memiliki kemampuan penalaran tinggi, sedang dan rendah jika dilihat dari kriteria penilaian penalaran matematis jawaban secara subtansi benar. Dengan hambatan kurangnya ketelitian, terpengaruh oleh rekan, kesalahan pada operasi hitung penjumlahan dan pengurangan sehingga terdapat beberapa kesalahan dalam menyelesaikan soal yang diberikan. Adapun, siswa dengan gaya belajar auditori dan memiliki kemampuan penalaran tinggi, sedang dan rendah dapat menyelesaikan soal penalaran matematis yang diberikan, berdasarkan hal tersebut siswa dengan gaya belajar tipe auditori yang memiliki kemampuan penalaran tinggi, sedang dan rendah jika dilihat dari kriteria penilain penalaran matematis jawaban secara subtansi benar dan lengkap dan sebagaian jawaban benar dengan atau lebih kesalahan atau kelalain yang signifikan. Dengan hambatan siswa lebih tertarik jika menyelesaikan soal dengan cara berdiskusi dan terdapat kesalahan pada operasi rumus phytagoras sehingga terdapat beberapa kesalahan dalam menyelesaikan soal yang diberikan. Selanjutnya siswa dengan gaya belajar kinestik dan memiliki kemampuan penalaran tinggi, sedang dan rendah dapat menyelesaikan soal penalaran matematis yang diberikan, berdasarkan hal tersebut siswa dengan gaya belajar kinestik yang memiliki kemampuan penalaran tinggi, sedang dan rendah jika dilihat dari kriteria penilaian penalaran matematis jawaban secara subtansi benar dan lengkap dan sebagaian jawaban benar dengan atau 
lebih kesalahan atau kelalain yang signifikan. Dengan hambatan siswa merasa bosan jika terusmenerus belajar di kelas, kurang minat terhadap mata pelajaran matematika dan tidak bisa diam sehingga waktu yang diberikan untuk mengerjakan soal banyak terbuang.

\section{REKOMENDASI}

Berdasarkan hasil penelitian bahwa untuk mengatasi kendala kemampuan penalaran matematis yang masih rendah dapat memaksimalkan pembelajaran matematika sesuai indikator kemampuan penalaran matematis yang digunakan. Peneliti selanjutnya mampu meneliti lebih lanjut mengenai kemampuan penalaran matematis berdasarkan gaya belajar siswa yang terdapat di sekolah lainnya, agar lebih sempurna lagi untuk dijadikan tolak ukur guru mengetahui gaya belajar yang dimiliki oleh siswa.

\section{UCAPAN TERIMAKASIH}

Peneliti mengucapkan terimakasih kepada kepala MTs Darul Ulum dan siswa kelas VIII MTs Darul Ulum Kecamatan Baregbeg tahun akademik 2020/2021 karena telah mendukung terhadap pelaksanaan penelitian ini. Selain itu, ucapan terimakasih juga ditujukan kepada pembimbing lbu Yoni Sunaryo, S.Pd., M.Pd., dan Ibu Angra Meta R, S. Pd., M.Pd dan menejemen program studi pendidikan matematika yang telah memberikan arahan dan motivasi kepada peneliti untuk menyelesaikan penelitian ini.

\section{DAFTAR PUSTAKA}

Baroody, A. J., \& Niskayuna, R. T. C. (1993). Problem solving, reasoning, and communicating, K-8. Helping Children Think Mathematically.

Ghufron, N. M., \& Risnawita, S. R. (2014). Gaya Belajar Kajian Teoritik. Yogyakarta (2nded). Pustaka Pelajar.

Hasrul. (2010). Pemahaman Tentang Gaya Belajar. Jurnal Medtek, 1(2), 1-9.

NCTM. (2000). Principles and Standards with The Learning Mathematics From Assesment Materials. Virginia: NCTM. Inc.

Sopiah, E, S., Effendi, A., \& Sunaryo, Y. (2020). Analisis Kemampuan Berpikir Kreatif Matematis Siswa Kelas VIII pada Materi Sistem Persamaan Linear Dua Variabel (SPLDV). J-KIP (Jurnal Keguruan dan Ilmu Pendidikan), 1 (2), 1-10.

Sopiatin, P., \& Sahrani, S. (2011). Psikologi Belajar dalam Perspektif Islam. Bogor: Ghalia Indonesia. 